International Journal of Current Microbiology and Applied Sciences

ISSN: 2319-7706 Volume 6 Number 4 (2017) pp. 99-109

Journal homepage: http://www.ijcmas.com

Original Research Article

https://doi.org/10.20546/ijcmas.2017.604.012

\title{
Green Synthesis of Copper Nanoparticles Using Momordica charantia Fruit Extracts and Evaluation of Their Anti-Microbial Efficacy
}

\author{
Flora-Glad Chizoba Ekezie $^{1}$, W. Jessie Suneetha ${ }^{1}$, K. Uma Maheswari ${ }^{1}$, \\ B. Anila Kumari ${ }^{1}$ and T.N.V.K.V. Prasad ${ }^{2}$
}

${ }^{1}$ Post Graduate and Research Centre, Department of Foods and Nutrition, Professor Jayashankar

Telangana State Agricultural University, Rajendranagar- Hyderabad, 500030, India

${ }^{2}$ Nanotechnology Laboratory, Institute of Frontier Technology, Regional Agricultural Research

Station, Acharya N.G Ranga Agricultural University, Tirupati 517502, India

*Corresponding author

A B S T R A C T

Keywords

Copper nanoparticles,

Momordica charantia,

antimicrobial activity,

agar well diffusion,

Disc diffusion, $S$.

aureus, $P$. aerogenosa,

E. coli and A. flavus.

Article Info

Accepted:

20 March 2017

Available Online:

10 April 2017
The development of nanotechnology interests the researchers for synthesis of nanoparticles with various bio-applications. The green synthesis of copper nanoparticles using Momordica charantia fruit extract acts as both reducing and capping agent. The biosynthesized CuNps were characterized by using UV-Vis analysis, Dynamic Light Scattering (DLS), Fourier Transform Infrared analysis (FTIR), X-ray diffraction analysis (XRD), Scanning Electron Microscopy (SEM) and Transmission Electron Microscopy (TEM) analysis. The synthesized CuNps were in spherical structure with an average size of particle size of $86.07 \mathrm{~nm}$. The Antimicrobial activity of the CuNps was established using disc diffusion and agar well diffusion method. The assay showed that CuNps can be a potent antimicrobial agent against Staphylococcus aureus, Pseudomonas aerogenosa and Escherichia coli with no inhibition against Aspergillus flavus.

\section{Introduction}

Recent research areas have been channeled to the development of anti-microbial agents from natural sources as there is an increasing trend in the emergence of resistance to synthetic anti-microbial drugs due to not only poor quality of drugs, patient non-compliance and irrational use of antimicrobial agents, but also to spontaneous mutations within the microbial populations. Primarily, multiple drug resistance (MDR) developed due to the indiscriminate use of commercial antimicrobial drugs to treat such infectious diseases (Dey et al., 2010). Owing to the side effects and the resistance that pathogenic micro organisms build against antibiotics as well diseases arising from oxidative stress, drastic measures should be adopted to control the use of anti-microbial agents. Many scientists are paying attention to medicinal plants with biologically active polyphenolic compounds isolated from plant species which possess anti-microbial, antioxidant and nutraceutical properties (Gin and Rigalleau, 2000). 
An emerging area of science used to optimize the efficiency of bioactive compounds responsible for the medicinal properties of plants is "Nanotechnology" as it's a precise and most advanced method of synthesizing highly stable bioactive compounds (Singh et al., 2010). Biological synthesis of nanoparticles from plants extracts slows enzyme kinetics for catalytic activity and offers better manipulation, control over the crystal growth and stability (Prasanth et al., 2011).

Now-a-days scientists are expanding interest in metal nanoparticles (zinc, copper, gold, silver, iron, gold and aluminum) as they provide superior material properties with functional versatility. Plant materials are also used as nanofabricators to promote green synthesis which is less expensive and less toxic (Singh, 2010).

Very few studies have been reported on the use of bitter gourd as a nanofabricator. Pandey (2012) reported the use of $M$. charantia extract for the facile synthesis of ultra-stable gold nanoparticles. Similarly, the green synthesis of silver nanoparticles in bitter gourd extract has been demonstrated by Bhor, 2014. For the first time, the present study reports the use of Momordica charantia for the biosynthesis of CuNps and its antimicrobial properties.

\section{Materials and Methods}

\section{Sample preparation}

Dried sample of Momordica charantia was subjected to exhaustive extraction by cold maceration in ethanol for 72 hours in conical flasks that were sealed to avoid evaporation. The slurry obtained was centrifuged at 3,000 rpm for 10 minutes and filtered through Whatman No.41 filter paper. The clear filtrate of $10 \mathrm{ml}$ was taken and mixed with $90 \mathrm{ml}$ aqueous solution of $1.0 \times 10^{-3} \mathrm{M}$ copper nitrate and incubated at room temperature for 24 hrs. The color change of copper nitrate indicates the formation of $\mathrm{CuNps}$ due to reduction of copper ion from $\mathrm{Cu}^{+2}$ to $\mathrm{Cu}$. The samples were then centrifuged at $4000 \mathrm{rpm}$ for 15 min to get a clear supernatant at room temperature.

\section{Characterization studies of CuNps}

UV - Visible Spectrophotometer was used to record the localized surface plasmon resonance of copper nanoparticles at $200-$ $800 \mathrm{~cm}^{-1}$. The size and morphology were examined using Dynamic Light Scattering (DLS), Scanning electronic Microscopy (SEM) and Transmission Electron Microscopy (TEM). FTIR spectrum was recorded in mid IR region in the range of 400 -4000 wavenumber $\left(\mathrm{cm}^{-1}\right)$. The structure of the nanoparticles was obtained from X-ray diffraction (XRD) technique.

\section{Determination of antimicrobial activity}

The effect of ethanol extract of $M$. charantia and its derivative copper nanoparticles on bacterial strains like Staphylococcus aureus, Escherichia coli and Pseudomonas aeruginosa and fungal strain of Aspergillus niger were assayed by agar well diffusion method and disc diffusion method as described by Pooloth, 2013.

\section{Statistical analysis}

All of the data from three independent replicate trials were subjected to analysis using Statistical package: Statistics 8.0. The data are reported as the mean + SD and significant differences between mean values were determined with one way analysis of variance (RBD) (Snedecor and Cochran, 1983). 


\section{Results and Discussion}

\section{Characterization studies}

\section{U.V Visible Spectrophotometer}

The absorption spectrum was recorded for the sample in the range of $200-800 \mathrm{~nm}$. The spectrum showed the absorbance peak at 235 - $250 \mathrm{~nm}$ corresponding to the characteristic localized surface plasmon resonance (LSPR) band of CuNps. The overall observations suggest that the bio-reduction of $\mathrm{Cu}^{+2}$ to $\mathrm{Cu}$ was confirmed with UV-Visible spectroscopy (Figures 1 and 2).

\section{Dynamic light scattering and zeta potential measurements}

DLS is a technique used to determine the size, size distribution profile and poly disparity index of particles in a colloidal suspension. The measurement results show the DLS and zeta potential to be $88 \mathrm{~nm}$ and $30.0 \mathrm{mV}$ respectively (Figures 3 and 4). The significance of zeta potential is that its value can be related to the stability of colloidal dispersions and also indicates the degree of repulsion between adjacent and similarly charged particles in dispersion (Sindhura et $a l ., 2014)$. The result shows the extracts were stable at room temperature.

\section{Scanning Electron Microscope and TEM}

SEM analysis was used to provide information about the morphology and size of the synthesized copper nanoparticles. Figure 5 shows that the nanoparticles formed were spherical in nature and were intactly coated with the material. The SEM micrograph also revealed the size of the nanoparticles was less than $100 \mathrm{~nm}$ (average value of $87.06 \mathrm{~nm}$ ) which confirms the feasibility of synthesizing copper nanoparticles using Momordica charantia as nanofabricator.

\section{FT-IR measurements}

The FTIR spectroscopy (Figure 6) of the ethanol extract coated with CuNps showed prominent peaks at $3354,1656,1653,1383$, 1165 and $426 \mathrm{~cm}^{-1}$ were due to $\mathrm{O}-\mathrm{H}$ stretching, $\mathrm{C}=\mathrm{N}$ stretching, $\mathrm{C}=\mathrm{O}$ stretching, $\mathrm{C}-\mathrm{H}$ group (aromatic), $\mathrm{C}-\mathrm{N}$ stretching (aliphatic amines) which were skeletal vibrations respectively. The majority of the IR bands were characteristic of triterpenes, proteins, steroids, carbohydrates, alkaloids and other compounds present in the solution. In particular, the broad and intense absorption peak at around $3354 \mathrm{~cm}^{-1}$ corresponded to the $\mathrm{OH}$ stretching vibrations of phenolic compound like gallic acid (David et al., 2014).

\section{X-Ray diffraction}

$\mathrm{XRD}$ is a very important method to characterize the structure of crystalline materials and used for the lattice parameters analysis of single crystals or the phase texture and stress analysis of sample. XRD pattern of synthesized CuNps from ethanol extract is shown in figure 7 . The sample demonstrated a good crystallinity level with diffraction angles of 32.43, 38.6, 44.80, 64.90, and 77.13 which correspond to the characteristic of face centered cubic of copper lines indexed at (111), (200), (200), (311) and (222).

\section{Antimicrobial properties}

The phytochemical profile of $M$. charantia fruit have indicated the presence of various secondary metabolites, that are known to have different therapeutic applications such as antihemorrhagic, antimicrobial and antioxidant properties (Supraja and Usha, 2013). In the present study, the antimicrobial efficacy CuNps and crude extracts were analysed using agar well and disc diffusion method. The results were represented as follows: 


\section{Disc diffusion method}

The antimicrobial activity of the crude and copper mediated nanoparticles of $M$. charantia extract were investigated measuring the zones of inhibition of bacterial and fungal species and were presented in table 1.

The antimicrobial activity against Staphylococcus aureus showed that CuNps had the highest zone of inhibition of 20.013 $\mathrm{mm}$ while the least zone of inhibition was for ethanol crude extract $(5.067 \mathrm{~mm})$ (Fig. 8a) and samples where significantly differed when compared at $\mathrm{p}<0.05$.

Similarly, the antimicrobial activity against $E$. coli was also screened (Fig. 8b). The result showed that the zone of inhibition was in the order; ampicillin $>\mathrm{CuNps}>$ crude extracts (i.e. $14.03 \mathrm{~mm}>11.07 \mathrm{~mm}>2.83 \mathrm{~mm}$ ). On the other hand, CuNps and crude extracts didn't have significant inhibitory activity against Pseudomonas aeruginosa (Fig. 8c). The present study also revealed that all the assayed samples showed no activity against the fungi Aspergillus flavus (Fig. 8d) and were comparable with studies of Kumar et al., 2010 showing active anti-bactericidal activity but no activity against fungi or yeast. The comparable antimicrobial of the green synthesized CuNps could imply that ethanol is the suitable media for liberation of phytochemical constituents screened (unpublished data) responsible for antimicrobial activity.

The antimicrobial activity of triterpenes depends on interaction between their lipid components with the net surface charge of microbial membranes. Furthermore, the bioactives might cross the cell membranes, penetrating into the interior of the cell and interact with intracellular sites critical for antibacterial activity (Trombetta et al., 2005). The mechanism by which the nanoparticles were able to penetrate the was due to changes in membrane morphology that significantly increases permeability and affects proper transport through the plasma membrane (Auffan et al., 2009; Brayner et al., 2006), leaving the bacterial cells incapable of properly regulating transport through the plasma membrane and resulting in cell death. It is also said that the nanoparticles penetrates inside the bacteria causing damage to phosphorus and sulfur containing compounds such as DNA (Kirchner et al., 2005).

Table.1 Antimicrobial activity of samples against selected micro organisms using disc diffusion method

\begin{tabular}{|c|l|l|l|l|l|}
\hline $\begin{array}{c}\text { S. } \\
\text { No }\end{array}$ & \multicolumn{1}{|c|}{ Sample } & $\begin{array}{c}\text { S. aureus } \\
\text { zone of } \\
\text { inhibition } \\
(\mathbf{m m})\end{array}$ & $\begin{array}{c}\text { P. aeruginosa } \\
\text { zone of } \\
\text { inhibition } \\
(\mathbf{m m})\end{array}$ & $\begin{array}{c}\text { E. coli } \\
\text { zone of } \\
\text { inhibition } \\
(\mathbf{m m})\end{array}$ & $\begin{array}{c}\text { A. niger } \\
\text { zone of } \\
\text { inhibition (mm) }\end{array}$ \\
\hline 1 & Crude ethanol extract & $5.07 \pm 0.02^{\mathrm{b}}$ & $2.07 \pm 0.05^{\mathrm{c}}$ & $2.83 \pm 0.03^{\mathrm{c}}$ & - \\
\hline 2 & CuNps & $20.013 \pm 0.02^{\mathrm{a}}$ & $9.51 \pm 0.02^{\mathrm{b}}$ & $11.07 \pm 0.04^{\mathrm{b}}$ & - \\
\hline 3 & Ampicillin & $4.97 \pm 0.06^{\mathrm{c}}$ & $19.80 \pm 0.2^{\mathrm{a}}$ & $14.03 \pm 0.04^{\mathrm{a}}$ & - \\
\hline
\end{tabular}

Key - No Inhibition

Note: Values are expressed as mean \pm standard deviation of triplicates. Mean values with similar superscripts within a column row do not difference significantly 
Table.2 Antimicrobial activity of samples against selected microorganisms using agar well diffusion

\begin{tabular}{|c|l|c|c|c|c|}
\hline $\begin{array}{c}\text { S. } \\
\text { No. }\end{array}$ & Sample & $\begin{array}{c}\text { S. aureus } \\
\text { Zone of Inhibition } \\
(\mathbf{m m})\end{array}$ & $\begin{array}{c}\text { P. aeruginosa } \\
\text { Zone of Inhibition } \\
(\mathbf{m m})\end{array}$ & $\begin{array}{c}\text { E. Coli } \\
\text { Zone of } \\
\text { Inhibition }(\mathbf{m m})\end{array}$ & $\begin{array}{c}\text { A. niger } \\
\text { Zone of } \\
\text { Inhibition }(\mathbf{m m})\end{array}$ \\
\hline 1 & Crude extract & $0.33 \pm 0.046^{\mathrm{e}}$ & $2.01 \pm 0.017^{\mathrm{e}}$ & - & - \\
\hline 2 & CuNps & $10.04 \pm 0.036^{\mathrm{a}}$ & $10.53 \pm 0.044^{\mathrm{a}}$ & - & - \\
\hline 3 & Ampicillin & $7.057 \pm 0.051^{\mathrm{b}}$ & $8.17 \pm 0.05^{\mathrm{b}}$ & - & - \\
\hline
\end{tabular}

Key - No Inhibition

Note: Values are expressed as mean \pm standard deviation of triplicates. Mean values with similar superscripts within a column row do not difference significantly.

Figure.1 Observed colour change after 24hrs - Formation of CuNps

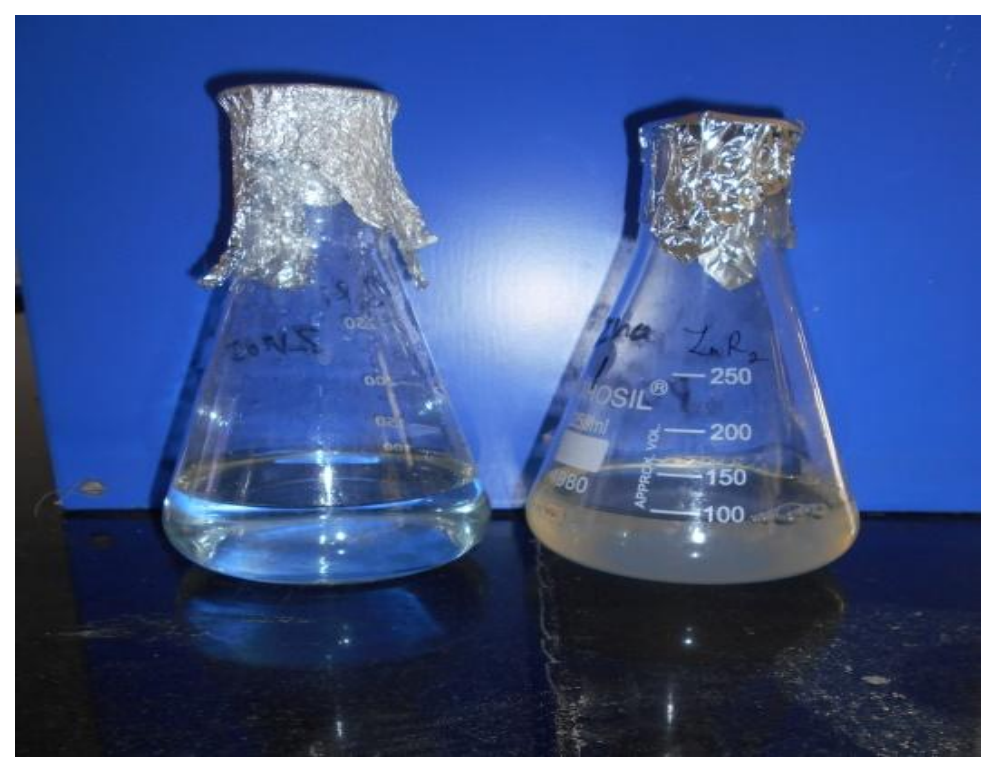

Figure.2 U.V Visible spectrum of CuNps synthesized from M. charantia

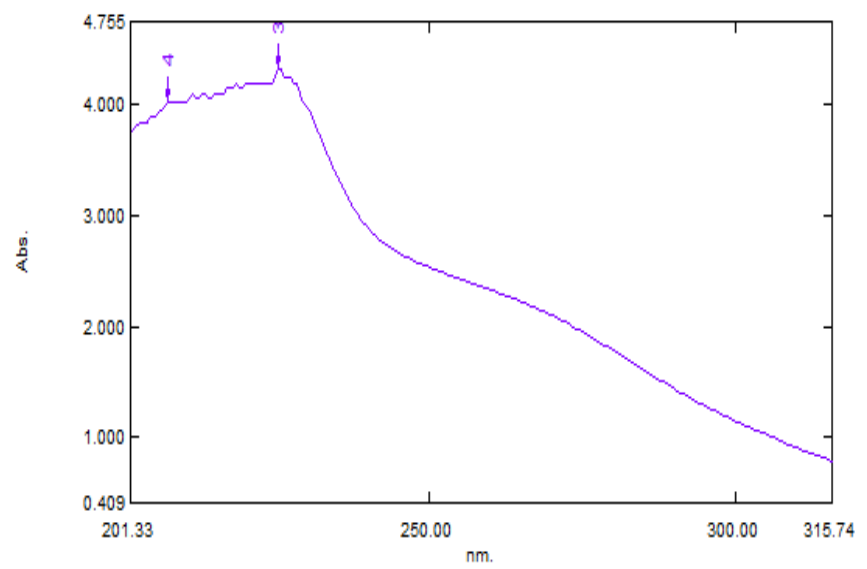


Figure.3 DLS measurment for CuNps synthesized from ethanol extract of

$$
\text { M.charantia }
$$

\section{Calculation Results}

\begin{tabular}{|c|ccccc|}
\hline Peak No. & S.P.Area Ratio & Mean & S. D. & Mode \\
\hline 1 & 1.00 & $98.4 \mathrm{~nm}$ & $25.2 \mathrm{~nm}$ & $88.0 \mathrm{~nm}$ \\
\hline 2 & - & $-\mathrm{nm}$ & $-\mathrm{nm}$ & $-\mathrm{nm}$ \\
\hline 3 & - & $-\mathrm{nm}$ & $-\mathrm{nm}$ & $-\mathrm{nm}$ \\
\hline Total & 1.00 & $98.4 \mathrm{~nm}$ & $25.2 \mathrm{~nm}$ & $88.0 \mathrm{~nm}$ \\
\hline
\end{tabular}

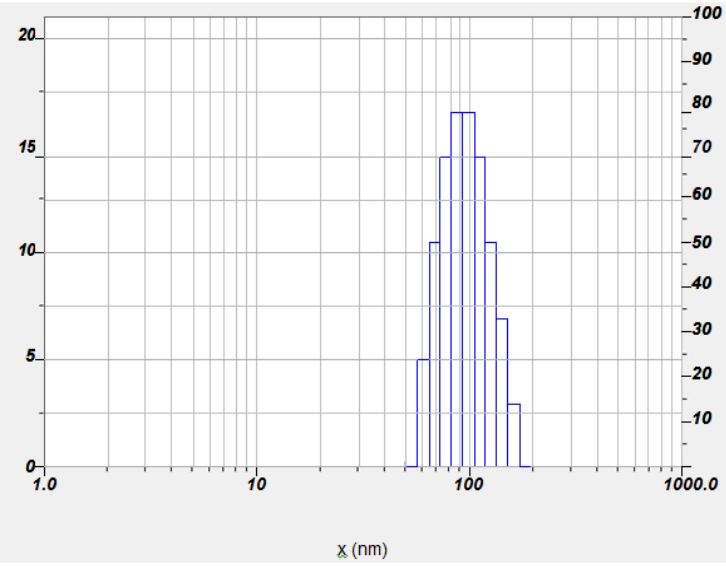

Figure.4 Zeta potential measurment for CuNps synthesized from ethanol extract of M.charantia

Calculation Results
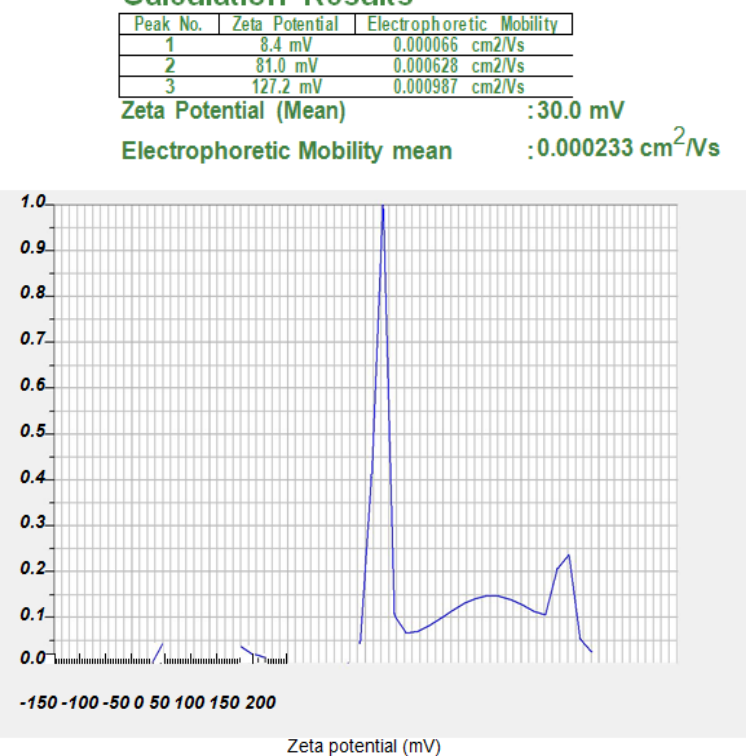

Figure.5 TEM image of CuNps synthesized from M. charantia

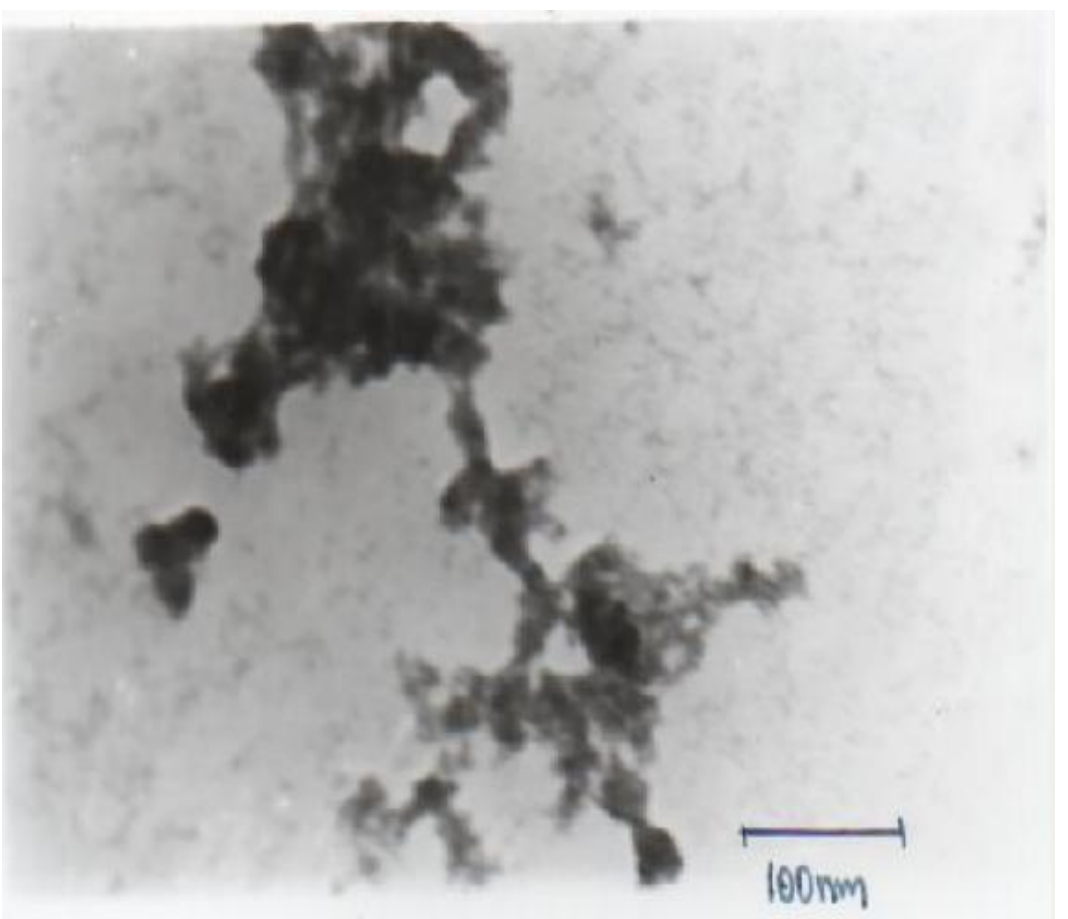


Figure.6 FTIR spectrum recorded from CuNps of $M$. charantia extract

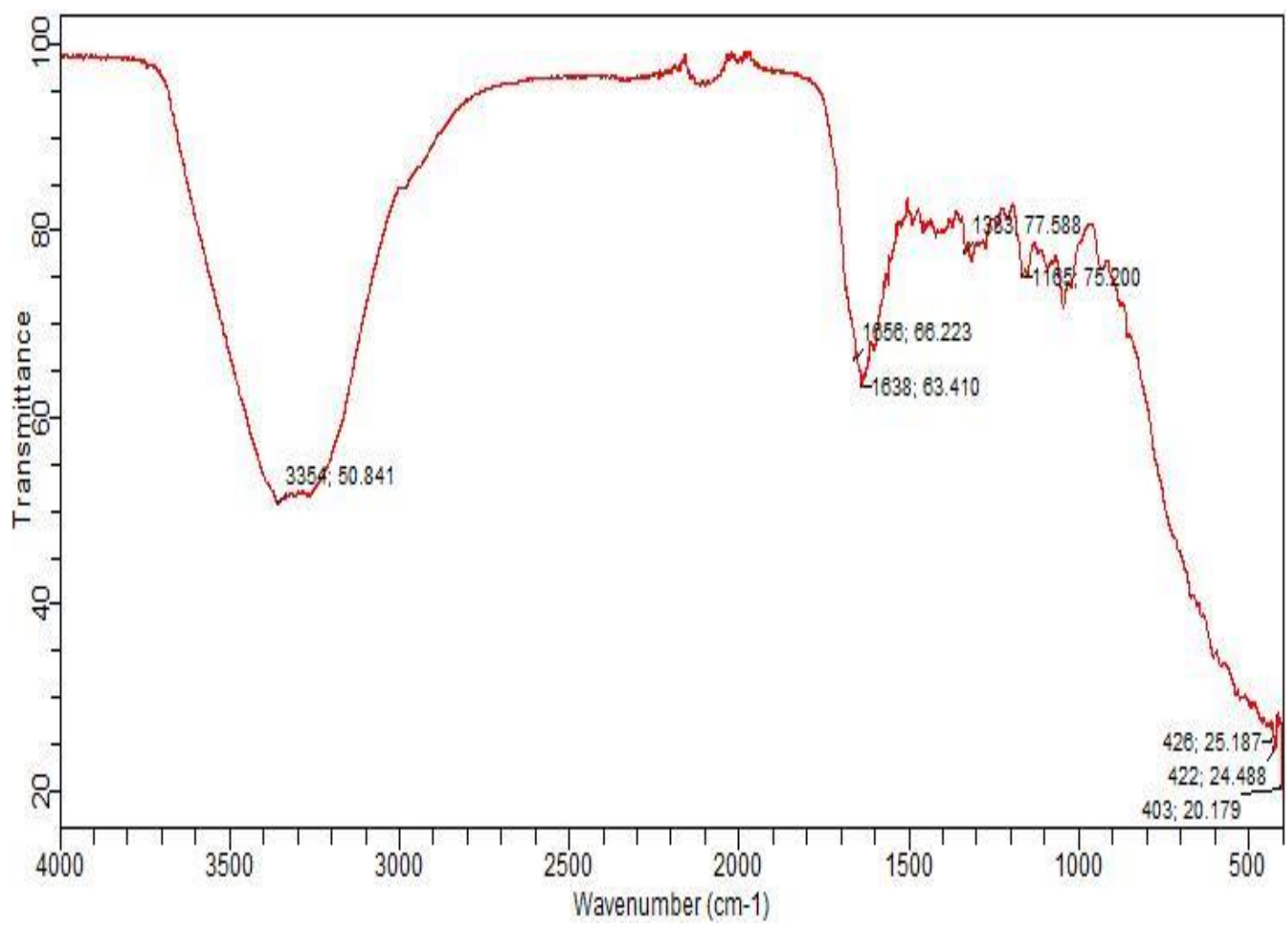

Figure.7 XRD micrograph of CuNps synthesized using ethanol extract of $M$. charantia

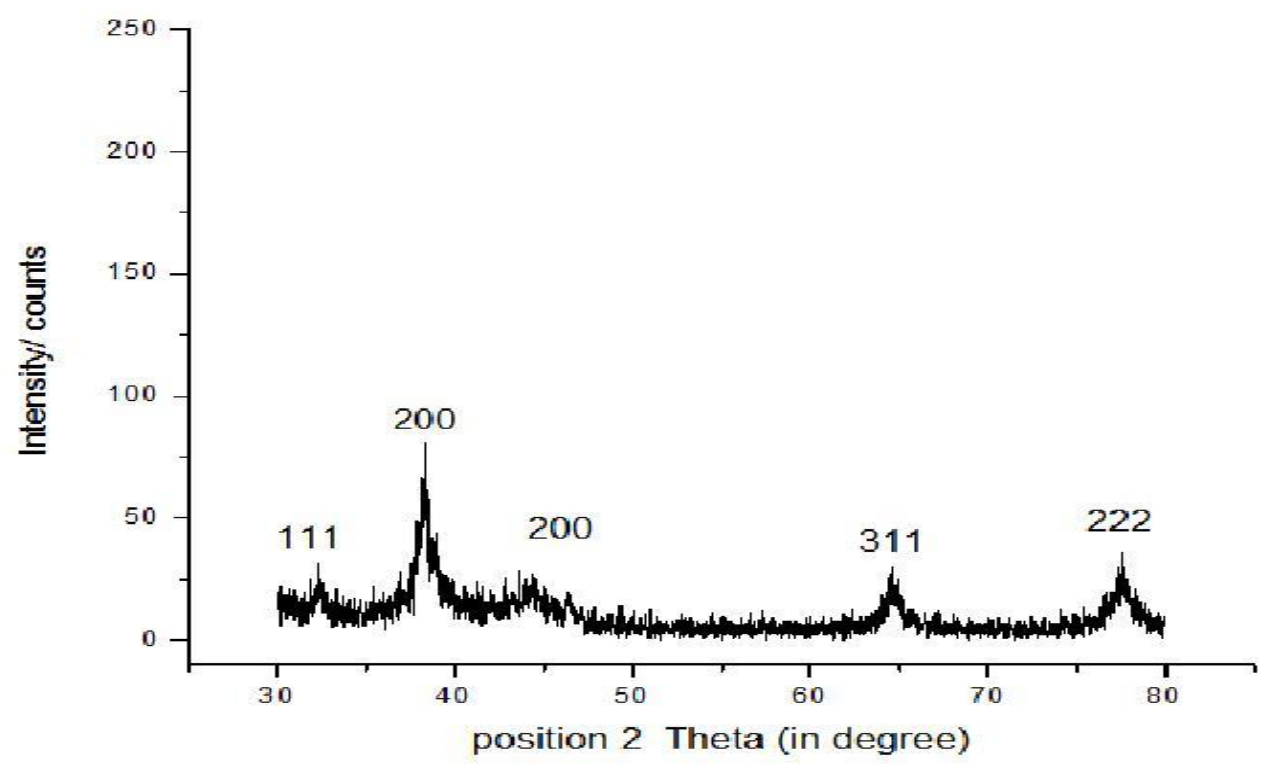


Figure.8 Antimicrobial activity of $M$. charantia against different micro organisms

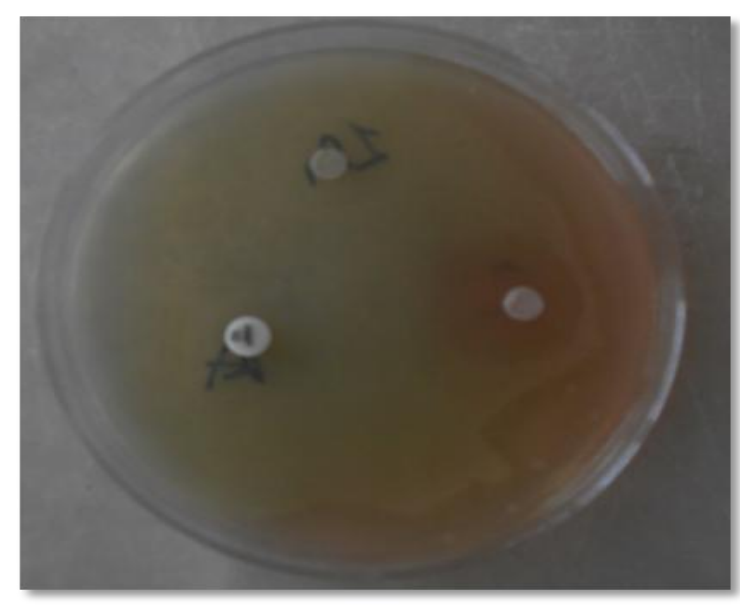

Figure.8a $S$.aureus

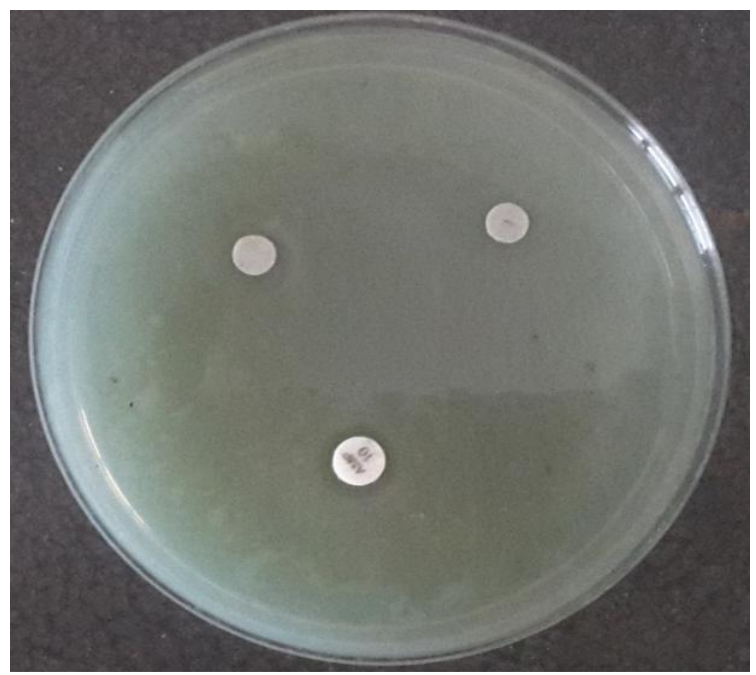

Figure.8c E. coli

Various researchers have also shown that gram positive bacteria are more susceptible to plant extracts than gram negative bacteria. The cell wall in gram positive bacteria is of a single layer whereas the gram negative cell wall is multi-layered (Parekh and Chanda, 2007).

The other possible mechanism of action, responsible for the enhanced activity of mediated CuNps could be the improved characteristics and morphological properties of nanoscale materials in terms of specificity and better manipulation, increased surface area available for interactions, which

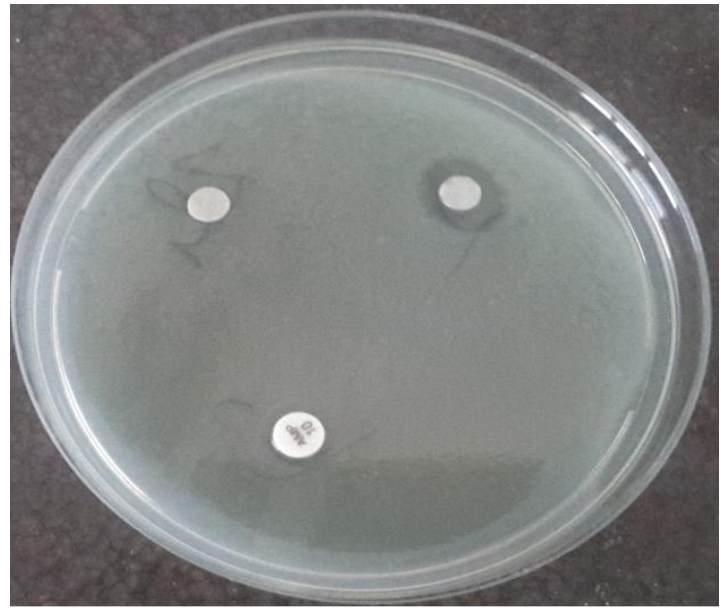

Figure.8b $P$. aeruginosa

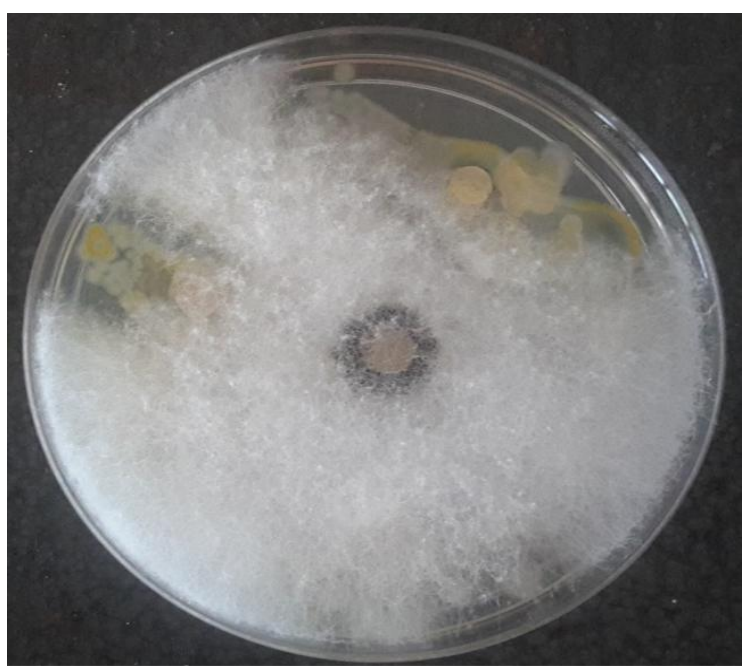

Figure.8d A. flavus

enhances bactericidal effect than the large sized particles and thus, they impart cytotoxicity to the microorganisms (Adams $e t$ al., 2006; Supraja et al., 2015).

\section{Agar well diffusion method}

The ethanol extract of $M$. charantia and its derivative CuNps were evaluated for their broad spectrum of activity on selected bacterial and fungal strains using agar well diffusion assay.

Staphylococcus aureus and Pseudomonas aeruginosa were sensitive to all the assayed 
samples while E. coli and Aspergillus flavus showed no sensitivity at all (Table 2). This justifies the traditional use of the plant against $S$. aureus with clinical significance against variety of suppurative (pus forming) infections and toxinoses in humans. Not in exception was $P$. aeruginosa which caused a good number of infections such as septic burns and wounds, conjunctivitis, endocarditis, meningitis and urinary tract infections (Michael et al., 1999).

Comparison of inhibition zones of the samples against $S$. aureus shows that the assayed crude extract was not as potent as the derivative $\mathrm{CuNps}$ and the standard ampicillin. Maximum inhibition was observed for $\mathrm{CuNps}$ $(10.057 \mathrm{~mm})$ which differed significantly from ampicillin $(7.057 \mathrm{~mm})$ at $\mathrm{p}<0.005$.

It has been reported that higher plants like wise show a promising potential source of new anti-microbial agents due to certain phytochemicals (Selvamohan et al., 2012). Inspite of this, it would not be unusual for $S$. aureus, E. coli and $P$. aeruginosa if they were resistant to the assayed extracts because of their multidrug resistance characteristics. The consistent observed resistance of A. flavus in both methods used in this study to evaluate the anti-microbial activity of $M$. charantia and its derivative nanoparticles might be attributable to the presence of more active enzymes in these microbes which deactivate the active antimicrobial components due to low affinity of the active component(s) on the target molecules. In line to our findings, other previous studies have demonstrated both invitro and in-vivo antibacterial activities against E. coli, Staphylococcus, Pseudomonas, Salmonella, Streptobacillus and Streptococcus by the plant extracts of bitter gourd (Ozusaglam and Karakoca, 2013).

Furthermore, copper which have been used as an anti-microbial agent for decades has revealed a strong antibacterial activity and showed good potency in this study. Copper oxide $(\mathrm{CuO})$ nanoparticles have been reported to act as potential antimicrobial agent against infectious organisms such as E. coli, Bacillus subtilis, Vibrio cholerae, Pseudomonas aeruginosa, Syphillis typhus, and Staphylococcus aureus (Shobha et al., 2014).

In conclusion, although the use of antibiotics has greatly reduced the incidence of infectious diseases, their extensive uses in therapy or as growth promoters in animal food has led to the appearance of drugresistant bacteria (Normanno et al., 2007), which is a major public health issue worldwide. In order to inhibit food-borne pathogens and to extend shelf life, synthetic chemicals are often used as preservatives in food processing and storage. Consumer awareness over the potential risks of synthetic food additives to human health has renewed the interest in using naturally occurring alternatives. Hence $M$. charantia extracts and nanoparticles screened for antimicrobial properties have potentials in protecting consumers from microbial infection and potential applications in food systems (Serra et al., 2008; Lou et al., 2010). The findings in this study may lead to the development of CuNps-based new antimicrobial systems for eco-friendly applications in packaging, preservation and storage of food as well as bactericidal, wound healing and other medical and electronic applications thus making it potentially exciting for industries.

\section{Acknowledgement}

The authors are thankful to ICAR for the award of African - Indian ICAR International Fellowship to Ms. Flora Glad Ekezie. The authors also thank Professor Jayashankar Telangana State Agricultural University and Acharya N G Ranga Agricultural University for facilitating the completion of research work. 


\section{References}

Adams, L.K., Lyon, D.Y and Alvarez, P.J.J. 2006. Comparative eco-toxicity of nanoscale $\mathrm{TiO}_{2}, \mathrm{SiO}_{2}$ and $\mathrm{ZnO}$ water suspensions. Water Res., 40: 3527-3532

Auffan, M., Rose, J., Bottero, J.Y., Lowry, G.V., Jolivet, J.P and Wiesner, M.R. 2009.Towards a definition of inorganic nanoparticles from an environmental, health and safety perspective. Nat Nanotechnol., 4: 634-641.

Bhor, G., Deokar, G., Hinge, S., Singh, L and Nalwade, A. 2014. Green synthesis of silver nanoparticles using fruit extract of bitter gourd and evaluation of their antibacterial activity against human and plant pathogenic bacteria. Int. J. $A d v$. Scientific and Technical Res., 4: 4.

Brayner, R., Ferrari-Iliou, R., Brivois, N., Djediat, S., Benedetti, M.F and Fievet, F. 2006. Toxicological impact studies based on Escherichia coli bacteria in ultrafine $\mathrm{ZnO}$ nanoparticles colloidal medium. Nano Lett., 6: 866-870.

David, S.A., Ponvel, K.M., Fathima, M.A., Anita, S., Ashli, J and Athilakshmi, A. 2014. Biosynthesis of silver nanoparticles by Momordica charantia leaf extract: Characterization and their antimicrobial activities. J. Nat. Prod. Plant Res., 4(6):1-8.

Dey, S.K., Banerjee, D., Chattapadhyay, S and Karmakar, B.2010. Antimicrobial activities of some medicinal plants of West Bengal. Int. J. Pharma and Bio Sci., 1(3): 1-10.

Gin, H. and Rigalleau V. 2000. "Post-prandial hyperglycemia and diabetes" Diabetes and Metabolism, 26: 265-272.

Kirchner, C., Liedl, T., Kudera, S., Pellegrino, T., Munoz, J.A., Gaub, H.E., Stolzle, S., Fertig, N and Parak, W.J. 2005. Cytotoxicity of colloidal CdSe and CdSe / ZnS nanoparticles. Nano Lett., 5:
331-338.

Kumar, D.S., Sharathnath, K.V., Yogeswaran, P., Harani, A., Sudhakar, K., Sudha, P and Banji, D. 2010. A Medicinal Potency of Momordica charantia. J. Pharmaceutical Sci. Rev. Res., 1: 2.

Lou, Z., H. Wang, W. Lv, C. Ma, Z. Wang, and S. Chen. 2010. Assessment of antibacterial activity of fractions from burdock leaf against food-related bacteria. Food Control, 21: 1272-1278.

Normanno, G., M. Corrente, G. La Salandra, A. Dambrosio, N.C. Quaglia, A. Parisi, G. Greco, A.L. Bellacicco, S. Virgilio, and G.V. Celano. 2007. Methicillinresistant Staphylococcus aureus (MRSA) in foods of animal origin product in Italy. Intern. J. Food Microbiol., 117: 219-222.

Ozusaglam, M.A and Karakoca. K. 2013. Antimicrobial and antioxidant activities of Momordica charantia from Turkey. African J. Biotechnol., 12(13): 1548-1558.

Pandey, S., Oza, G., Mewade, A. and Sharon, M. 2012. Green synthesis of highly stable gold nanoparticles using Momordica charantia as nano fabricator. Archives of Appl. Sci. Res., 2(2):1135-1141.

Parekh, J. and Chanda, S. 2007. In-vitro screening of antibacterial activity of aqueous and alcoholic extracts of various Indian plant species against selected pathogens from Entero bacteriaceae. African J. Microbiol. Res., 1(6): 92-99.

Patra, A.K. 2012. An overview of antimicrobial properties of different classes of phytochemicals. In: Patra AK (Ed.), Dietary phytochemicals and microbes, XII; 1-32.

Pooloth, J. 2013. Biosynthesis of silver nanoparticles using Trigonella foenum graecum and the determination of their antimicrobial activity. Int. J. Sci. Res., 
2(5): 2319-7064.

Prasanth, S., Menaka, I., Muthezhilan, R and Sharma, N.K. 2011. Synthesis of plant mediated silver nanoparticles using medicinal plant extract and evaluation of its anti-microbial activities. Int. J. Eng. Sci. Technol., 3: 6235-6259.

Selvamohan, T., Ramadas, S.V. and Kishore, S.S. 2012. Antimicrobial activity of selected medicinal plants against some selected human pathogenic bacteria. Adv. Appl. Sci. Res., 3(5): 3374-3381

Shoba, F.G., Babu, V.A., Parimala, $\mathrm{M}$ and Sathya, J. 2014. In - vitro Evaluation of Antimicrobial Activity of Moringa oleifera and Momordica charantia seeds 5(5): 1988-1993.

Singh, A., Jain, D., Upadhyay, M.K., Khandelwal, N and Verma H.N. 2010. Green synthesis of silver nanoparticles using Argemone mexicana leaf extract and evaluation of their antimicrobial activities. Dig. J. Nanomater. Biostruct, 5(2): 483-489.

Sindhura, K.., Prasad, T.N.V.K.V., Selvam, P.P., and Hussain O.M. 2014. Synthesis, characterization and evaluation of effect of phytogenic zinc nanoparticles on soil exo-enzymes. Appl. Nanosci., 4: 819827.

Supraja, P. and Usha, R. 2013. Antibacterial and phytochemical screening from leaf and fruit extracts of Momordica Charantia Int. J. Pharm. Bio Sci., 4(1): 787-793.

Supraja, N., Prasad, T.N.V.K.V and Krishna, T.G and David, E. 2015. Synthesis, characterization, and evaluation of the antimicrobial efficacy of Boswellia ovalifoliolata stem bark-extractmediated zinc oxide nanoparticles. Appl. Nanosci., 204: 15-20.

Taylor, L. 2002. Herbal secrets of the rainforest. In: Texas A, editor. Bitter melon (Momordica charantia) 2nd ed. USA: Sage Press; pp. 1-100

Trombetta, D., Castelli, F., Sarpietro, M.G., Venuti, V et al., 2005. Mechanisms of Antibacterial action of three monoterpenes. Antimicrobial Agents Chemometer, 49(6): 2474-2478.

\section{How to cite this article:}

Flora-Glad Chizoba Ekezie, W. Jessie Suneetha, K. Uma Maheswari, B. Anila Kumari and T.N.V.K.V. Prasad. 2017. Green Synthesis of Copper Nanoparticles Using Momordica charantia Fruit Extracts and Evaluation of Their Anti-Microbial Efficacy. Int.J.Curr.Microbiol.App.Sci. 6(4): 99-109. doi: https://doi.org/10.20546/ijcmas.2017.604.012 